\title{
A very rare Renal Sarcoma: Renal Leiomyosarcoma containing heterologous sarcomas - Malign Mesenchymoma
}

\author{
Çok ender bir Renal Sarkom: Heterelog sarkomlar içeren Renal \\ Leiyomyosarkom - Malign Mezenkimom
}

Serkan ŞENOL ${ }^{1}$, Asıf YILDIRIM² ${ }^{2}$, Ebru ZEMHERi ${ }^{1}$, Elvan TURFANDA ${ }^{1}$, Şeyma ÖZKANLI ${ }^{1}$

ABSTRACT

Malign mesenchymoma which consists of about $10 \%$ of renal malignancies is very rarely seen among mesenchymal neoplasies of the kidney. Malign mesenchymoma which has a worse prognosis is characterized by the presence of more than 2 accompanied sarcomas with underlying spindle cells. We report a novel case of this rare tumor together with literature review.

Key words: Kidney, sarcoma, malign mesenchymoma
Öz

Tüm böbrek malignitelerinin yaklaşık \%10'unu oluşturan mezenkimal neoplaziler içerisinde malign mezenkimoma oldukça enderdir. Prognozu kötü seyreden bu antitede ikiden fazla sarkom türünün bir arada olması ve zemininde iğsi hücreli sarkomun eşlik etmesi ile karakterizedir. Oldukça ender görülen bu tümör literatür verileri eşliğinde tartışılmıştır.

Anahtar kelimeler: Böbrek, sarkom, malign mezenkimom

\section{GiRiş}

Malign mezenkimom andiferansiye veya fibrosarkomatöz alanlara ek olarak birbirinden keskin hatlarla ayrılan en az iki ayrı tip ve bariz malign mezenkimal diferansiyasyon gösteren ender bir yumuşak doku tümörüdür ${ }^{1,2}$. Terminolojik olarak daha çok heterolog farklanma gösteren leiomyosarkom terimi kullanılmaktadır. En sık görülen birlikteliği rabdomyosarkom-liposarkom veya rabdomyosarkom-osteo/kondrosarkomdur ${ }^{3,4}$. Tümörün en sık yerleşim yeri retroperiton olmakla birlikte, farklı lokalizasyonlarda da geliştiği bildirilmiştir. Az diferansiye sarkom olan bu tümörlerin prognozları kötü ve nüksleri sıktır. Bu olguda oldukça ender görülen bu tümör, çok daha ender lokalizasyonu nedeni ile öncelikle histopatolojik bulguları ve ayırıcı tanıları yönünden literatür bilgileri ışığında sunulmuştur.
OLGU

Elli üç yaşında kadın hasta yan ağrısı ve uylukta kitle nedeniyle polikliniğe başvuran hastanın yapılan radyolojik incelemesinde, sağ böbrek alt pole tutunmuş halde $7 \mathrm{~cm}$ çapında, sağ uyluk ön yüzde kas dokusu arasında $3 \mathrm{~cm}$ çapında ve karaciğerde, metastaz ile uyumlu en büyüğü $2 \mathrm{~cm}$ çapta birkaç adet kitle izlendi. Bunun üzerine parsiyel nefrektomi ve eksizyon yapılarak her iki kitle de patoloji bölümüne gönderildi. Makroskopik olarak renal kitle, kirli beyaz renkte, santrali kanamalı ve nekrotik alanlar içeren yer yer solit sert kıvamda (Figür 1); uyluktaki kitle solit beyaz renkte, lifsel görünümde idi. Mikroskopik olarak uyluktaki kitlede kollajenize ve fokal miksoid stroma arasında, yer yer pleomorfik görünümde, hiperselüler atipili iğsi hücreler izlendi. Tipik mitoz 10 büyük büyütme alanında 3 olarak tespit edildi (Figür 2). İmmünohistokimyasal incelemede malign hücreler düz

Received: 12.09 .2015

Accepted: 28.09.2015

${ }^{1}$ İstanbul Medeniyet Üniversitesi Göztepe Eğitim ve Araştırma Hastanesi, Patoloji Anabilim Dalı

2̇̇stanbul Medeniyet Üniversitesi Göztepe Eğitim ve Araştırma Hastanesi, Üroloji Anabilim Dalı

Yazışma adresi: Uzm. Dr. Serkan Şenol, Dr. Erkin Cad. Göztepe Eğitim ve Araştırma Hastanesi Patoloji Kliniği, 34743-İstanbul

e-mail: drserkansenol@yahoo.com 


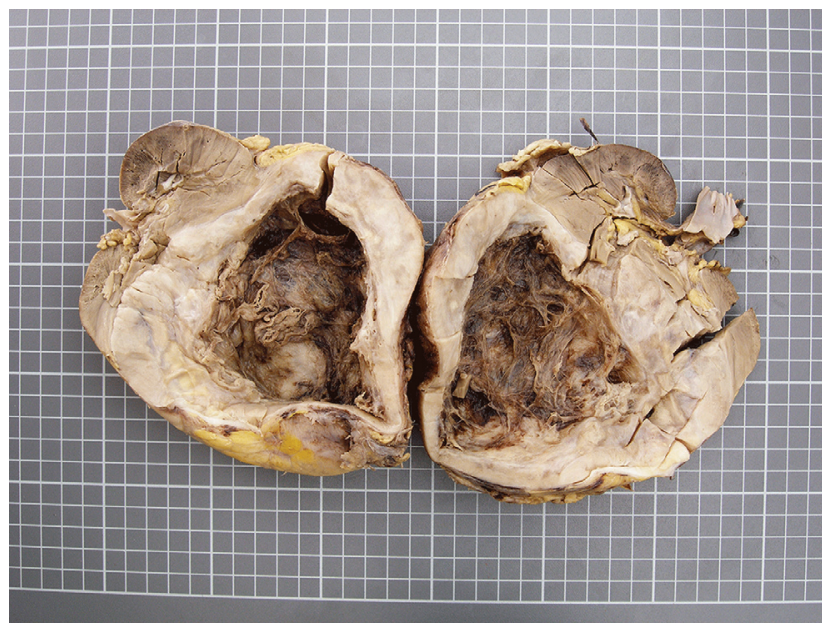

Figür 1. Ortası kanamalı, kistik ve nekrotik solit krem beyaz renkli böbrek çeperi kitlesi.

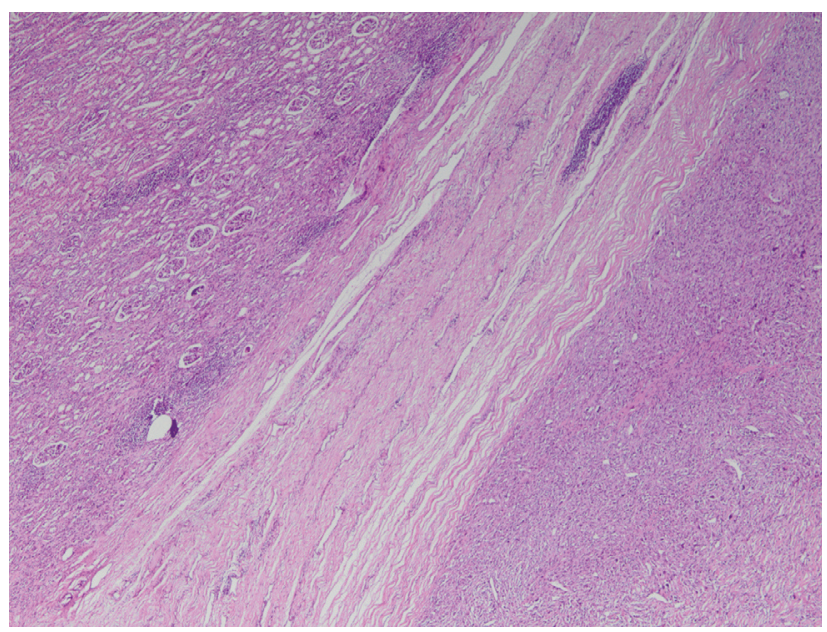

Figür 3. Sol taraf börek dokusu, ortada kapsül ve sağ taraf malign mezenkimal tümör alanı (H\&E x40).

kas aktini, desmin ve kaldesmon ile pozitif, S-100, pansitokeratin, myogenin negatifti. Böbrekteki kitlede ise uyluktaki bulgulara ilave olarak leiyomyosarkomatöz dokunun içerisinde mikroskobik olarak böbrek dokusu ile keskin bir hatla ayrılmış malign natürde osteosarkomatöz ve kondrosarkomatöz difaransiyasyon alanlarının eşlik ettiği tümöral kompleks izlendi (Figür 3,4). Ayrıca fokal hemanjioperisitom benzeri alanlar mevcuttu. Bu sonuçlardan sonra olgu böbreğin heterolog (osteosarkom ve kondrosarkom) farklanma odakları içeren leiomyosarkom/ malign mezenkimom olarak rapor edildi. Uyluktaki kitle ise böbrekteki kitlenin metastazı olarak değerlendirildi.

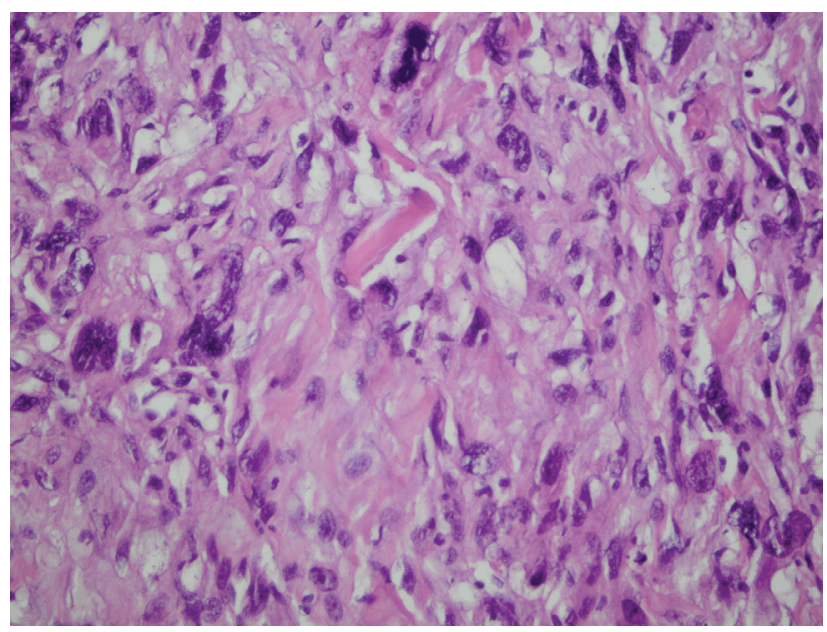

Figür 2. Selüler, atipili ve pleomorfik leiyomyosarkom alanı (H\&E x200).

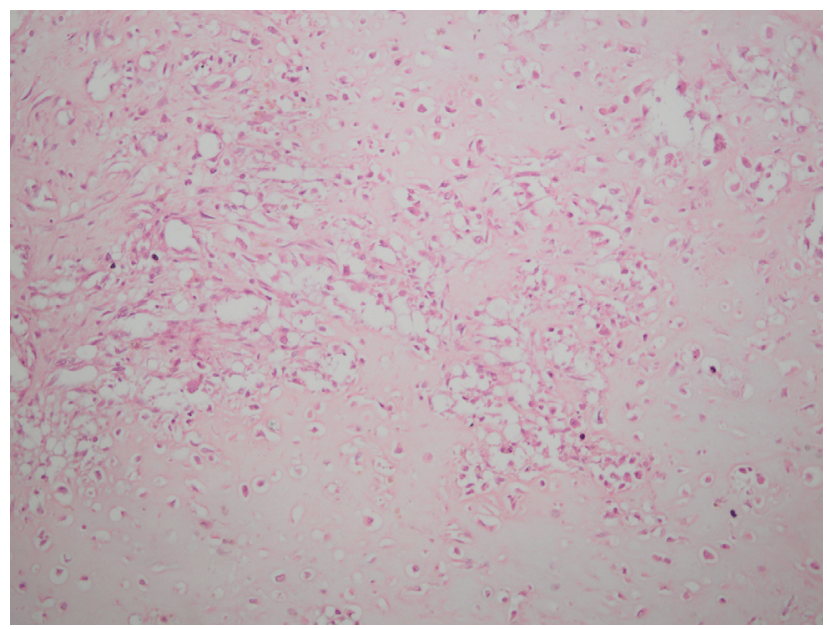

Figür 4. Osteokondrosarkomatöz alan (H\&E x100).

\section{TARTIŞMA}

Malign mezenkimoma oldukça ender görülen agresif gidişatlı high grade malign bir tümördür. Genellikle retroperitonium ve uylukta yerleşim gösterirler. Bunun dışında karaciğer, özofagus, mesenter, mesane, larinks, plevra ve kalp lokasyonları da sporadik olarak rapor edilmiştir². Primer lokasyon olarak böbrek ise çok çok enderdir ${ }^{5}$. Öyle ki Dünya Sağlık Örgütünün üriner sistem tümörleri patoloji kitabının böbrek tümörleri bölümünde isim olarak bile geçmemektedir. Ortalama görülme yaşı 55'tir. 
Leiyomyosarkom, pleomorfik sarkom, fibrosarkom, dediferansiye liposarkom, rabdomyosarkom gibi antitelerden farkı, tekil sarkomlarda görülebilen metapastik matür kıkırdak ve kemik dediferansiye alanlarının metaplastik değil sarkomatöz olmasıdır ${ }^{4}$.

Böbrek lokalizasyonunda ayırıcı tanısına anaplastik wilms tümörü, primer renal sinovial sarkom, anaplastik sarkom, ektomezenkimoma ve mezenkimal kondrosarkom alınabilir. Bu antitelerin ayrımında morfolojik farklılıklarının yanında immünohisttokimyasal yöntemler yardımcıdır. Ayırıcı tanıda en az iki tip malign mezenkimal tümöre andiferansiye veya fibrosarkom alanlarının eşlik ediyor olması malign mezenkimom lehine önemli bir kriterdir ${ }^{4,6}$.

Malign mezenkimal tümörlerin genelde yumuşak dokudan organa veya organdan organa metastaz yapmaları beklenirken, olgumuzda böbrekten uyluk kasına (organdan yumuşak dokuya) metastazı izlendi.

Tam total eksizyon malign mezenkimomun hâlâ bilinen en etkin tedavisi olup, kemo-radyoterapinin etkisi sınırlıdır.

\section{KAYNAKLAR}

1. Stout AP. Malignant mesenchymoma: the mixed tumor of mesenchymal derivatives. Ann Surg 1948;127:278.

http://dx.doi.org/10.1097/00000658-194802000-00007

2. Enzinger FM, Weiss SW. Malignant soft tissue tumors of uncertain type. Soft Tissue Tumors. $5^{\text {th }}$ edition. Philadelphia, Mosby Elsevier, 2008: 1213-16.

3. Newman PL, Flechter CDM. Malignant mesenchymoma. Clinicopathologic analysis of a series with evidence of lowgrade behavior. Am J Surg Pathol 1991;15:607-14. http://dx.doi.org/10.1097/00000478-199107000-00001

4. Brady MS, Perino G, Tallini G, et al. Malignant mesenchymoma. Cancer 1996;77:467-73. http://dx.doi.org/10.1002/(SICI)1097-0142(19960201)77: 3<467::AID-CNCR7>3.0.CO;2-H

5. Vujanić GM, Kelsey A, Perlman EJ, et al. Anaplastic sarcoma of the kidney: a clinicopathologic study of 20 cases of a new entity with polyphenotypic features. Am J Surg Pathol 2007;31:1459-68. http://dx.doi.org/10.1097/PAS.0b013e31804d43a4

6. Goldsby RE, Bruggers CS, Brothman AR, et al. Spindle cell sarcoma of the kidney with ganglionic elements (malignant ectomesenchymoma) associated with chromosomal abnormalities and a review of the literature. J Pediatr Hematol Oncol 1988;20:160-64.

http://dx.doi.org/10.1097/00043426-199803000-00015 